\title{
REVISITANDO A HISTÓRIA DA EDUCAÇÃO POPULAR NO BRASIL: EM BUSCA DE UM OUTRO MUNDO POSSÍVEL
}

\author{
Dulcinéia de Fátima Ferreira Pereira ${ }^{1}$ \\ Eduardo Tadeu Pereira ${ }^{2}$
}

\begin{abstract}
RESUMO
Por meio da retrospectiva histórica da Educação popular no Brasil, o presente artigo pretende reafirmar seu papel transformador do contexto de globalização da exclusão, no qual vivemos atualmente, pois se acredita que a Educação popular pode reacender a "chama da esperança" nas classes populares. Esta análise se inicia no final dos anos 40, período em que os ideais democráticos se expandem pela sociedade brasileira, passando pelos anos 50 e 60, quando surgem as ideias de Paulo Freire, que deram origem ao trabalho da Educação popular e que, mais tarde, se transformariam em um marco nas ideias pedagógicas no Brasil e no mundo. Foram também analisados os movimentos de resistência nos anos 70, o retorno à mobilização popular nos anos 80 e as consequências das políticas neoliberais instaladas no Brasil nos anos 90. Identifica-se, por fim, o novo cenário do século XXI, que apresenta à Educação popular seus desafios e a possibilidades neste tempo de transição paradigmática: trata-se de reacender a "chama da esperança", resgatando a participação social das classes populares, rumo à construção de uma sociedade mais justa e mais humana.
\end{abstract}

Palavras-chave: Educação popular, história da Educação, Paulo Freire, Boaventura de Sousa Santos.

\section{REVISITING THE HISTORY OF POPULAR EDUCATION IN BRAZIL: IN SEARCH OF ANOTHER WORLD POSSIBLE}

\begin{abstract}
Through the historical background of Popular Education in Brazil, this paper intends to reassert its role in transforming the context of globalization we are living in exclusion, because they believe that Popular Education can rekindle the flame of hope in the popular classes. This analysis starts from the end of 40 years, during which democratic ideals are expanded by Brazilian society, through the ' 50 s and ' 60 s, when there are the ideas of Paulo Freire, who led the work of Popular Education and later to transformed into a landmark in the pedagogical ideas in Brazil and worldwide. We also analyzed the resistance movements in the '70s, the return to popular mobilization in the ' $80 \mathrm{~s}$ and the consequences of neoliberal policies installed in Brazil in 1990. Identifies, finally, the new scenario of the XXI century, which presents the Popular Education challenges and opportunities in this time of paradigm shift: it is to rekindle the flame of hope, redeeming social participation of the popular classes toward building a society more just and more humane.

Keywords: Popular Education, history of Education, Paulo Freire, Boaventura de Sousa
\end{abstract} Santos. 


\title{
Introdução
}

A Educação popular nasceu fora da escola, no seio das organizações populares, mas seus princípios e sua metodologia, com bases emancipatórias, tiveram uma repercussão tão grande na sociedade que acabaram cruzando fronteiras e os muros das escolas, influenciando práticas educativas, tanto as que acontecem nos espaços escolares, como as que ocorrem em outros espaços educativos, como nos sindicatos, nas ONGs, Associações de Moradores, Reuniões do Orçamento Participativo (OP), nos conselhos populares etc. Seus desafios não são pequenos nos dias atuais.

Falar em Educação popular é falar do conflito que move a ação humana em um campo de disputas de forças de poder. É falar da forma como o capitalismo neoliberal vem atuando de forma perversa, causando dor e sofrimento humanos. É uma possibilidade de retomarmos o debate proposto por Paulo Freire acerca da conscientização, da compreensão da realidade e de nossa ação no mundo. É falar de uma práxis educativa cujo ponto de partida é a realidade social.

A Educação popular tem como princípio a participação popular, a solidariedade rumo à construção de um projeto político de sociedade mais justo, mais humano e mais fraterno.

\begin{abstract}
A Educação popular acompanha, apóia e inspira ações de transformação social. Nela, o processo educativo se dá na ação de mudar padrões de conduta, modos de vida, atitudes e reações sociais. Portanto, se a realidade social é ponto de partida do processo educativo, este volta a ela para transformá-la. (WERTHEIN, 1985, p. 22)
\end{abstract}

A forma como a sociedade capitalista organiza-se hoje é bem diferente do período em que os debates sobre Educação popular iniciaram-se. O mundo mudou. As formas de controle e de poder mudaram; estão mais complexas e sofisticadas e, portanto, difíceis de ser identificadas por olhos menos atentos. Nunca foi tão contrastante a distância entre os saberes produzidos pela humanidade e a precariedade da vida. No contexto atual, deparamo-nos com as armadilhas da globalização neoliberal ${ }^{3}$.

Podemos dizer, a partir de Santos (2000), que vivemos as consequências das grandes promessas feitas pela Modernidade há pelo menos 200 anos, “[...] que permanecem incumpridas ou o seu cumprimento redundou em efeitos perversos" (ibidem, p. 23). Enfrentamos problemas que parecem não ter solução!

Cada vez mais, o capitalismo se "[...] constitui um excelente ambiente para dinamizar a produção, mas não soube até hoje criar mecanismos eficientes de distribuição. $\mathrm{Na}$ realidade, a própria estrutura de poder gerada pelos privilégios e pelo enriquecimento de minorias torna inviável a distribuição equilibrada" (DOWBOR, 1995, p. 10).Esse contexto provoca-nos inquietações, indignação e inconformismo. Temos motivos de sobra para retomar o debate sobre a Educação popular, pois entendemos que este é um território que ainda não foi totalmente colonizado pelo modelo neoliberal. É justamente em uma situação como a que vivemos hoje que o trabalho, em uma perspectiva popular, ganha novas dimensões. A Educação popular apresenta-se como um movimento de resistência, de "descolonização dos horizontes", como uma possibilidade de "abrir janelas".

Simbolicamente, esse movimento de "abrir janelas" significa a possibilidade de reacendermos a "chama da esperança", lembrando-se que "[...] a esperança é necessária, mas não é suficiente. Ela só não ganha a luta, mas, sem ela, a luta fraqueja e titubeia" (FREIRE, 1992, p. 10). 
Por meio da retrospectiva histórica da Educação popular no Brasil, pretendemos, neste texto, reafirmar seu potencial transformador do contexto de globalização da exclusão em que estamos vivendo. Acreditamos que a Educação popular pode contribuir para reacender "a chama da esperança" das classes populares, pois propõe uma relação educativa que vai além do trabalho com conteúdos escolares, vai em busca da formação do homem-pessoa, ao invés do homem-coisa ${ }^{4}$, do homem como um ser social comprometido com as causas de seu tempo, insatisfeito, curioso, sonhador, esperançoso e fundamentalmente transformador.

O que possibilita à Educação popular ser um território de reinvenção do modo como estamos vivendo e, portanto, de transformação do mundo é o fato de estar organicamente vinculada aos princípios da educação dialógica proposta por Paulo Freire (1987); nesse sentido, jamais dicotomiza o homem do mundo, respeita a vocação ontológica do homem de ser mais, estimula a criatividade humana, ama a vida em seu devir (é biófila), valoriza a relação educador-educando e educando-educando, reconhece o homem como um ser histórico, da práxis, e tem do saber uma visão crítica, pois este encontra-se submetido a condicionamentos históricos-sociológicos, uma vez que não há saber sem busca inquieta, sem a aventura do risco de criar.

Ao acreditar no potencial humano e estimular a participação dos educandos, a Educação popular transforma-se em um laboratório de experimentação em que vários níveis de atuação vão se fazendo presentes. $\mathrm{O}$ educando vai encontrando no grupo um apoio para experimentar sua capacidade de pensamento, argumentação e criação.

A Educação popular explicita o lado político da educação e ganha um caráter de classe, na medida em que questiona a forma como as relações de poder que sustentam a sociedade capitalista reproduzem-se na educação bancária ${ }^{5}$ e que orienta as atividades para a construção de um projeto histórico nacional voltado para a criação de uma sociedade justa e igualitária, enfatizando a solidariedade de todos os setores que possam compartilhar esse projeto. Podemos dizer que "os projetos de Educação popular são os que implicam ao mesmo tempo maiores desafios e maiores potencialidades, tanto educacionais como sociais" (WERTHEIM, 1985, p. 60).

Inconformados com o contexto de desvalorização das experiências populares, optamos, neste artigo, por realizar um estudo sobre a Educação popular no Brasil. Uma análise histórica se fez necessária para que pudéssemos identificar suas origens, seus desafios, perspectivas de atuação e possibilidades.

\section{Uma retrospectiva histórico-política da Educação popular}

O final da década de 40 foi um período em que questões relacionadas à Educação de base começam a aparecer no país, pois "[...] até a Segunda Guerra Mundial, a Educação popular era concebida como a extensão da educação formal para todos, sobretudo para os habitantes das periferias urbanas e zonas rurais" (VALE, 1992, p. 7).

A educação de base era entendida como o processo educativo destinado a proporcionar a cada indivíduo os instrumentos indispensáveis ao domínio da cultura de seu tempo, em técnicas que facilitassem o acesso a essa cultura - como a leitura, a escrita, a aritmética elementar, noções de ciências, de vida social, de civismo, de higiene - e com as quais, segundo suas capacidades, cada homem pudesse desenvolver-se e procurar melhor ajustamento social (BEISIEGEL, 1989, p. 14). 
O final da II Guerra Mundial trouxe para o mundo a vitória dos ideais democráticos; essa conjuntura internacional interferiu nas mobilizações nacionais da época que acabaram dando ênfase ao movimento pela educação das massas. Na medida em que se buscava o progresso social e econômico da nação, tornava-se necessário pensar em uma política de Educação de base, na qual, além da alfabetização, a população tivesse acesso a um ajustamento social, ou seja, buscava-se a adaptação dos desfavorecidos ao mundo moderno.

A atenção principal voltava-se para o homem do campo, que até então só conhecia uma experiência basicamente rural. Era preciso que ele tivesse acesso a noções de leitura, escrita, convivência social e até mesmo de higiene, para poder conviver com as exigências da vida moderna, tornando-se, assim, mais apto para a produção e até mesmo para a defesa da nação.

Naquele momento viveu-se no Brasil, formal e constitucionalmente, uma democracia. Aliás, foi muito cedo que as elites brasileiras, assim como em outras partes da América Latina, aprenderam a lidar com os mecanismos formais da democracia liberal. $\mathrm{O}$ populismo ${ }^{6}$ é uma dessas estratégias, ou melhor, um mecanismo real de controle de todas as instâncias de democracia pelos membros das camadas dominantes, ainda que, diferentemente dos períodos anteriores, o povo tivesse o direito formal de participar.

$\mathrm{Na}$ década de 50, alguns educadores iniciaram um debate acerca da Educação de Jovens e Adultos (EJA), questionando se ela era apenas uma transmissora de conteúdos ou uma possibilidade de difusão de ideias. Eles começaram a se preocupar com o enfoque de seu trabalho, não querendo mais que este fosse apenas um transmissor de programas préestabelecidos. Para esses educadores, uma Educação destinada às camadas populares não poderia ficar presa somente à transmissão de conteúdos; pensava-se na formação de pessoas críticas, conscientes.

Segundo Paiva (1987), no final da década de 50, aconteceu o II Congresso Nacional de Educação de Adultos, em que educadores manifestaram diferentes posições relacionadas à nova perspectiva educacional. Dentre essas concepções, encontramos o pensamento de Paulo Freire, o qual atrai vários adeptos, como: educadores, intelectuais, estudantes, líderes comunitários de todo o país, em prol de uma Educação popular que "[...] preconizava a alfabetização e a conscientização de todos" (BEISIEGEL, 1989, p. 15).

Paulo Freire, juntamente com outros educadores, sugeriu: a revisão dos transplantes que agiram sobre o nosso sistema educativo, a organização de cursos que correspondessem à realidade existencial dos alunos, o desenvolvimento de um trabalho educativo com o Homem e não para o Homem, a criação de um grupo de estudo e de ação dentro do espírito de autogoverno, o desenvolvimento de uma mentalidade nova no educador, que deveria passar a sentir-se participante do trabalho de soerguimento do país; e, finalmente, a renovação dos métodos e processos educativos com a rejeição daqueles exclusivamente auditivos, substituindo o discurso pela discussão e utilizando as modernas técnicas de educação de grupos com a ajuda de recursos audiovisuais. (PAIVA, 1987, p. 210)

Esse período foi marcado por mobilizações em favor da Educação popular. Nele se iniciou uma luta para que se mudasse a visão preconceituosa que se tem sobre o analfabeto, como um ser incapaz, deficiente. À frente desse movimento, encontramos marxistas e cristãos. Pode-se afirmar que esse processo vai se afunilando principalmente na luta contra o preconceito ao analfabeto, juntamente com a luta pelo seu direito ao voto. Ocorre 
também a difusão dos ideais de Paulo Freire, que começa a perguntar: "A serviço de quem educamos? Para quem educamos? O que ensinamos? Como ensinamos?".

Para Freire, a Educação não poderia ser vista apenas como ferramenta para a transmissão de conhecimentos e reprodução das relações de poder instituídas no capitalismo, como acontecia na Educação bancária (cf. FREIRE, 1987), mas, sim, como uma ação capaz de libertação e emancipação das pessoas. "Uma prática cultural libertadora deveria envolver um trabalho intelectual de reelaboração dos elementos ideológicos da tradição de um povo" (BRANDÃO, 2008, p. 28).

Na primeira metade dos anos 60, os movimentos voltaram-se à promoção da cultura popular, questionando-se não apenas sobre a "[...] forma ingênua e folclórica" (FÁVERO, 1983) como se pensava a cultura do povo brasileiro, mas também, e principalmente, sobre os usos políticos de dominação e alienação da consciência das classes populares. Começaram a brotar, no Brasil, movimentos voltados para a promoção da cultura popular, dos quais Freire participou. Juntamente com outras pessoas, fundou e participou do Movimento de Cultura Popular de Recife (MCP) ${ }^{7}$. Esse movimento tinha a intenção de levar a todas as pessoas a cultura produzida pelo povo. O MCP pretendia trabalhar com

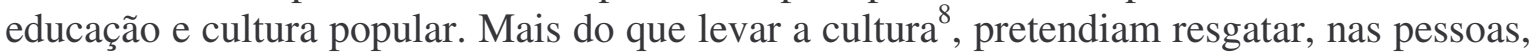
o seu potencial criador. Reafirmavam, na prática, que todo ser humano produz cultura na sua relação com o outro e com o mundo.

A liberdade de expressão, característica dos últimos anos do governo Kubitschek, e a efervescência política dos primeiros anos da década de 60 contribuíram para que estudantes, intelectuais, educadores e políticos se preocupassem com a promoção das massas e o processo de tomada de consciência.

Este "movimento" reuniu professores e artistas. Ele não existia só nas escolas e nem era um trabalho só da educação [...] as pessoas que faziam o MCP queriam que tudo o que é bom, e está nas palavras, nas cantigas, e nas idéias que as pessoas criam, fosse levado para a gente pobre também. (BRANDÃO, 2001, p. 35)

O que se pretendia era a construção de um projeto político que possibilitasse superar a dominação do capital sobre o trabalho e, assim, reformular tudo que dessa dominação decorria.

Nesse mesmo período, Freire desenvolveu uma experiência em alfabetização de adultos "[...] na cidade de Angicos, no Rio Grande do Norte, em 1962" (CALDART \&KOLLING, 2001, p. 9). Esse processo não surgiu do nada, ele vinha sendo gestado há um certo tempo.

Há mais de 15 anos vínhamos acumulando experiências no campo da educação de adultos, em áreas proletárias e subproletárias, urbanas e rurais. [...] Sempre confiávamos no povo. Sempre rejeitávamos fórmulas doadas. Sempre acreditávamos que tínhamos algo a permutar com ele, nunca exclusivamente a oferecer-lhe. Experimentamos métodos, técnicas, processos de comunicação. Superamos procedimentos. Nunca, porém, abandonamos a convicção que sempre tivemos de que só nas bases populares, e com elas, poderemos realizar algo sério e autêntico para elas. (FREIRE, 1982a, p. 102)

Preocupado com o papel político da Educação e temendo que o trabalho com jovens e adultos se transformasse em um processo de invasão cultural ${ }^{9}$, Freire propôs uma educação para a liberdade (cf. FREIRE, 1974), pois defendia a reflexão, o debate em 
torno do potencial criador dos educadores, das educadoras, bem como dos educandos e das educandas.

Nessa educação para a liberdade, a partir da participação no círculo de cultura ${ }^{10}$, os homens e as mulheres se redescobririam como produtores de cultura, compreenderiam a relação do ser humano com a natureza e a possibilidade de transformarem o mundo por seu potencial criador. Perceberiam que a Educação não é algo distante da vida, mas, sim, a possibilidade de recriá-la e, assim, vivê-la melhor. Freire propunha a conscientização ${ }^{11}$, não a transmissão ou memorização das letras.

Essa experiência de alfabetização, a partir dos princípios da educação para a liberdade, procurava superar a educação domesticadora, ou Educação bancária como assim denominou. Para Freire, a Educação popular seria um espaço em que o homem ultrapassaria sua situação de homem-objeto a homem sujeito-histórico transformador. $\mathrm{O}$ que se pretendia era a construção de um projeto político que possibilitasse superar a dominação do capital sobre o trabalho e, assim, reformular a forma de organização da sociedade.

\begin{abstract}
Diversos grupos lançam-se ao campo da atuação educativa com objetivos políticos claros e mesmo convergentes, embora cada um deles enfocasse o problema à sua maneira e mesmo lutassem entre si. Pretendiam todos a transformação das estruturas sociais, econômicas e políticas do país, sua recomposição fora dos supostos da ordem vigente; buscavam criar a oportunidade de construção de uma sociedade mais justa e mais humana. Além disso, fortemente influídos pelo nacionalismo, pretendiam o rompimento dos laços de dependência do país com o exterior e a valorização da cultura autenticamente nacional, a cultura do povo. (PAIVA, 1987, p. 230)
\end{abstract}

Esses grupos buscavam uma forma de trabalho que contribuísse para a mobilização e participação popular. Paiva também afirma que grupos cristãos ${ }^{12}$, influenciados pela nova doutrina social da Igreja $^{13}$, sustentavam esse trabalho com enfoque político-social transformador.

A conjuntura do país começava a dar sinal de mudança. Os militares, que já vinham se articulando politicamente, com raízes vinculadas aos interesses econômicos internos e externos, com respaldos sociais expressivos e comprometidos com o capital estrangeiro, começam a ameaçar o governo com a possibilidade de golpe. Em 1 de abril de 1964, instala-se no país o Regime Militar.

Conforme Pereira (2008), a instauração da ditadura militar em 1964 e seu aprofundamento em 1968, culminado com o Ato Institucional $\mathrm{n}^{\circ} 5$ (AI-5), leva ao distanciamento total da população do poder, inibindo qualquer tipo de participação popular nele. Os artigos $2^{\circ}, 3^{\circ}, 4^{\circ}$ e $10^{\circ}$ do AI-5 são particularmente muito expressivos em relação ao autoritarismo que se instalou no Brasil e ao fechamento do regime a qualquer possibilidade de participação popular. No artigo $2^{\circ}$ lê-se que "O Presidente da República poderá decretar o recesso do Congresso Nacional, das Assembléias Legislativas e das Câmaras Municipais" (Diário Oficial da União, 13 de dezembro de 1968, apud SILVA, 1992 , p. 298). No $3^{\circ}$, temos que "O Presidente da República $\square \ldots \square$ poderá decretar a intervenção nos Estados e Municípios" (Idem). No artigo $4^{\circ}$, apresenta-se a possibilidade de "suspender os direitos políticos de quaisquer cidadãos $\square$... $\square$ e cassar mandatos eletivos Federais, Estaduais e Municipais" (Idem, p. 299), e no $10^{\circ}$ decreta-se que "Fica suspensa a garantia de habeas-corpus" (Idem).

Com essas restrições, a participação restringia-se ao voto em algumas periódicas 
eleições. Nelas, eram eleitos vereadores e prefeitos de cidades que não fossem capitais ou que não tivessem algum interesse estratégico (como portos, por exemplo, considerados como "área de segurança nacional"), além de deputados estaduais, deputados federais e senadores. E assim permaneceu até 1977, quando o povo passa a eleger dois terços do Senado, mas sendo a parte restante formada por senadores que não eram eleitos diretamente, denominados de "senadores biônicos".

Além disso, os governadores e o Presidente da República eram eleitos indiretamente, reduzindo ao mínimo a participação popular na democracia liberal brasileira. Qualquer outra perspectiva de participação era vetada e combatida com os instrumentos de força, legalizados e institucionalizados (como o DOI-CODI Destacamento de Operações Internas e Comando Operacional de Defesa Interna e a Oban - Operação Bandeirantes, por exemplo) ou não, como era o caso do Comando de Caça aos Comunistas (CCC).

Nessa dinâmica, repressora e autoritária, os sindicatos sofreram intervenções e muitas de suas diretorias foram trocadas. No lugar delas foram colocados "interventores", sujeitos fiéis aos donos do poder e a seus interesses políticos e econômicos. As entidades estudantis, por sua vez, foram proibidas e a censura cuidava da imprensa, impedida de livremente fazer circular as informações. Por maior que fosse a dureza do regime político consolidado no Brasil a partir do AI-5, ele não conseguiu sair ileso das atrocidades que cometeu. (PEREIRA, 2008, p. 29)

A ampliação e intensa mobilização dos programas de Educação popular passam a ser ameaçadores para a nova ordem vigente. Para os militares, as ideias que vinham sendo difundidas nos grupos de cultura e Educação popular poderiam tornar o processo político incontrolável; por isso rotularam de subversivos os que estavam engajados nessas formas de atuação política.

A repressão violenta atingiu todos os movimentos dos trabalhadores comprometidos com as causas populares. Intervenções militares aconteceram nos sindicatos e nas universidades, visando à desarticulação e à desmobilização popular. Logo após o golpe militar, iniciou-se o processo de desaparecimento dos grupos de Educação popular.

Com objetivos políticos de silenciamento dos movimentos de Educação popular, em 1967, o governo militar cria o Movimento Brasileiro de Alfabetização (Mobral). O Mobral fazia restrições claras à concepção político-filosófica de Paulo Freire. Esse movimento estimulava o individualismo e a adaptação à vida moderna, enfatizando a responsabilidade pessoal pelo êxito ou fracasso e tentando afastar a possibilidade de resistência ao modelo instalado.

Sob fortes esquemas de controle e tortura, muitas fissuras políticas, sociais e institucionais começaram a aparecer no regime militar, não tendo sido suficientes as mais cruéis perseguições, torturas e mortes provocadas àqueles que contra ele bravamente se levantavam. Movimentos populares de resistência começam a se fazer presentes no subterrâneo das ações militares e a se espalhar pelo país em forma de guerrilhas armadas e organizações clandestinas.

Aproveitando-se dessas fissuras e agindo de forma a recompor as forças, uma série de iniciativas políticas, sociais, culturais, e até mesmo religiosas ${ }^{14}$, conseguiram articular os setores populares e alterar de maneira nada desprezível a correlação de forças sociais. Como "[...] na corda bamba de sombrinha" ${ }^{15 ", ~ a ~ E d u c a c ̧ a ̃ o ~ p o p u l a r ~ f o i ~ u m ~ d e s s e s ~}$ movimentos que se refugiaram em Organizações Não-governamentais (ONGs)ou mesmo em trabalhos desenvolvidos pelas Comunidades Eclesiais de Base (CEBs). 
Não é pura coincidência que a crise da ditadura militar, vivenciada no final dos anos 70, coincidiu com a ascensão dos movimentos sociais no Brasil. Durante essa década, outras formas de manifestar oposição ao regime foram surgindo. Mais uma vez o povo volta às ruas, embora a repressão ainda existisse de forma disfarçada. Aumentaram os movimentos contra o custo de vida, movimentos pela anistia, pela democracia e abertura política. Os movimentos populares ganharam corpo, retornaram às ruas, com greves, manifestações políticas e se espalharam pelo Brasil.

\begin{abstract}
Matrizes vão dar origem ao movimento social na década de 70, a Igreja Católica, os remanescentes das organizações de esquerda e o novo sindicalismo. [...] a prática social da militância das pastorais e comunidades e a "Educação Popular" por ela desenvolvida era o paradigma do período, influenciando e acolhendo os militantes dispersos que só aí encontravam possibilidades de contato e trabalho político com setores populares. (PEREIRA, 2006, p. 31)
\end{abstract}

Os anos da década de 1980 do século XX, conhecida como a "década perdida" pelas perdas econômicas dos países da América Latina, foram paradoxalmente aqueles em que no Brasil se viveu um período de enorme crescimento da organização popular e de suas experiências de participação política na sociedade. Segundo Saviani (1995), podemos afirmar que sob o ponto de vista da organização do campo educacional, a década de 80 é uma das mais fecundas de nossa história, pois a mobilização desses anos orientou-se pela bandeira de transformar a Educação e a escola em instrumentos de reapropriação do saber por parte dos trabalhadores; saber este que viria, mais tarde, a contribuir para uma maior participação na sociedade.

Esse novo momento de ascensão das forças populares, que se iniciou como período histórico em 1978, com a greve da Scania (empresa/fábrica), perdura até o processo de impeachment do presidente Fernando Collor de Melo, em 1992. Nesses anos, o país viu nascer e desenvolver o mais forte movimento de organização e participação popular de sua história, que nem mesmo a crise resultante da implantação do neoliberalismo, levado a cabo no governo Fernando Henrique Cardoso, conseguiu desmontar.

Foi justamente nessa década não perdida, período histórico que compreende os anos de 1978 a 1992, que vimos nascer o Partido dos Trabalhadores (PT), em 1980, a Central Única dos Trabalhadores (CUT), em 1983, e o Movimento dos Trabalhadores Rurais Sem Terra (MST), em 1985.

Sob a perspectiva do avanço das forças populares no terreno da política, esse foi um período riquíssimo, não perdido, já que nele uma infinidade de organizações e instrumentos de luta social surgiram e consolidaram-se, colocando os trabalhadores do campo e da cidade em melhores condições de disputa de poder na sociedade, fortalecendoos para que fizessem valer seus interesses frente aos da elite política e econômica.

Juntamente com a mobilização popular, a abertura política vai ganhando corpo. Nosso país começa a mudar "sua cara". No campo da Educação "[...] a década de 80 se inicia com a construção de entidades destinadas a congregar educadores e de associações de caráter sindical que vão se aglutinando em âmbito nacional" (SAVIANI, 1995, p. 52). As organizações dos educadores caracterizam-se pela preocupação com o significado político e social da Educação, além do aspecto econômico-corporativo.

Em 1982 aconteceu a primeira eleição direta para governadores de Estado desde 1965, após lutas por redemocratização do país. Infelizmente, “[...] não por acaso, os governos civis desse período, que sucedem a ditadura militar, cada qual no seu estilo, 
também tentam destruir as bases fundamentais desse processo de organização da sociedade" (ALENCAR, 1987, p. 20).

Com o processo de democratização, novas manifestações encheram as praças e ruas do Brasil. Em 1984, a luta pelas "Diretas" foi o maior movimento de massas que o Brasil já viveu. Outra grande mobilização popular foi em defesa da Assembleia Nacional Constituinte, que resultou, em 1988, na nova Constituição Nacional, conhecida como "constituição cidadã", por trazer em seu bojo algumas conquistas da classe trabalhadora, dentre elas, o direito ao voto do analfabeto e a obrigatoriedade, juntamente com a gratuidade do ensino fundamental, independente da idade de quem o procure.

A definição da noção de cidadania, empreendida pelos movimentos sociais e por outros setores sociais na década de 80 , aponta na direção de uma sociedade mais igualitária em todos os seus níveis, baseada no reconhecimento dos seus membros como sujeitos portadores de direitos, inclusive aquele de participar efetivamente da gestão da sociedade. (DAGNINO, 2002, p. 10)

Como conquista da mobilização popular Diretas já, em 1989, o Brasil viveu um momento político profundamente significativo: a eleição do primeiro presidente pelo voto direto após longos anos de ditadura militar.

Esta eleição 'marca uma disputa muito acirrada pela hegemonia da sociedade, materializando-se pela oposição entre dois projetos políticos claros e distintos: o Projeto Neoliberal e o Projeto Democrático Popular. O Projeto Neoliberal, proposta das elites dominantes, traz como objetivo principal a chamada política de modernização da economia, construída sobre os pilares da privatização e desregulamentação.

O Projeto Democrático Popular, proposta dos setores organizados do povo brasileiro, traz fundamentalmente o fim da submissão aos interesses externos (FMI), a justa distribuição das riquezas produzidas, a garantia da igualdade de oportunidades e a elaboração de políticas sociais capazes de responder às demandas das camadas populares, gerando melhorias concretas em suas condições de vida. (MEB, 1993, p. 17)

Com o governo do presidente Fernando Collor de Mello, o neoliberalismo instalase no Brasil dando origem à expansão da exclusão social, à privatização, ao aumento do desemprego, à terceirização de serviços, bem como ao sucateamento dos serviços públicos nas áreas sociais, como moradia, saúde, educação, dentre outras.

Com o governo Collor, o Brasil atravessou, no início dos anos 90, “[...] uma crise moral e ética, alimentada pela corrupção, pelos desvios de recursos que não excluem nem mesmo a Presidência da República. [...] O impedimento a Collor foi um grande protesto ético da sociedade brasileira contra a corrupção, a impunidade e o aproveitamento de recursos públicos para enriquecimento particular" (MEB, 1993, p. 21).

O povo voltou às ruas com o movimento "Fora Collor"; muitos grupos populares, partidos, organizações, sindicatos etc. "abraçaram" a luta pela dignidade. Em meio a essa mobilização, o povo brasileiro deu uma grande contribuição para a democratização do país, deu um grande exemplo de cidadania. Com o impeachment de Collor, assumiu em seu lugar o vice-presidente, Itamar Franco, que não barrou o avanço do neoliberalismo. 
Em 1994, novas eleições presidenciais, e, mais uma vez, o projeto neoliberal venceu as eleições com Fernando Henrique Cardoso. FHC realizou um governo totalmente articulado com a ideologia e a política neoliberal, portanto, com o capital internacional, aprofundando ainda mais as políticas de exclusão social.

Com a globalização da economia, pudemos ver, no final dos anos 80, a política neoliberal instalando-se, silenciosamente, no Brasil. Com ela, conhecemos a face mais perversa do capitalismo: a progressiva segregação e exclusão ${ }^{16}$.

\title{
Entre a globalização hegemônica e a globalização contra-hegemônica: desafios e possibilidades
}

Com a política neoliberal, vemos um cenário caótico de incertezas, de trivialização dos conflitos e dos sofrimentos humanos. Não tem sido fácil viver neste território marcado por tamanhas discrepâncias. A “[...] coexistência destes excessos confere ao nosso tempo um perfil especial, o tempo caótico onde ordem e desordem se misturam em combinações turbulentas. [...] As rupturas e as descontinuidades, de tão freqüentes, tornam-se rotina, e a rotina, por sua vez, torna-se catastrófica" (SANTOS, 2000, p. 41).

Os cânones do neoliberalismo expressam-se no "pacote" do Consenso de Washington, que pode ser resumido, segundo Santos,

\begin{abstract}
Nas seguintes exigências e orientações: as economias nacionais devem se abrir ao mercado mundial e os preços locais devem tendencialmente adequar-se aos preços internacionais; deve ser dada prioridade à economia de exportação; as políticas monetárias e fiscais devem ser orientadas para a redução da inflação e da dívida pública e para a vigilância sobre a balança de pagamentos; os direitos de propriedade devem ser claros e invioláveis; o setor empresarial do Estado deve ser privatizado; a tomada de decisão privada, apoiada por preços estáveis, deve ditar os padrões nacionais de especialização, a mobilidade dos recursos, dos investimentos e dos lucros; a regulação estatal da economia deve ser mínima; deve reduzir-se o peso das políticas sociais no orçamento do Estado, reduzindo o montante das transferências sociais, eliminando sua universalidade, e transformando-as em meras medidas compensatórias em relação aos estratos sociais equivocadamente vulnerabilizados pela atuação do mercado (SANTOS, 2001, p. 35).
\end{abstract}

Esse "[...] evangelho da economia de mercado" (STIGLITZ, 2002, p. 180) transforma não apenas os mecanismos de orientação econômica como também as noções de justiça, direitos, solidariedade, enfim, cidadania, que são trocadas por noções como poder de compra, competitividade, enfim, noções de consumidores. É a aplicação prática da pregação, feita em ambiente desfavorável por muito tempo, dos ultraliberais, como Hayek e Friedman.

Com a implantação das políticas neoliberais, assistimos ao desmantelamento das mobilizações sociais sem o enfrentamento direto e armado. Com os movimentos sociais enfraquecidos, a Educação popular vive consequências no interior de sua prática cotidiana. Muitos educadores populares também passaram a se questionar sobre a viabilidade de transformação da sociedade. Muitos, inclusive, são capturados pela lógica do mercado, entregando-se a uma visão fatalista da história.

O traço político mais perigoso da onda neoliberal é que esta se propõe como a única alternativa possível, válida para toda sociedade. Articula-se, estreitamente, com a ideia de 
que a história já terminou, consolidando-se o esquema democrático liberal. Acabar com a esperança de que um outro mundo é possível ${ }^{17}$ parece ser o intento do neoliberalismo.

A ideologia fatalista, imobilizante, que anima o discurso neoliberal, anda solta no mundo. Com ares de pós-modernidade, insiste em convencer-nos de que nada podemos contra a realidade social, que de histórica e cultural, passa a ser ou virar "quase natural". Frases como "a realidade é assim mesmo, o que podemos fazer?" ou "o desemprego no mundo é uma fatalidade do fim do século" expressam bem o fatalismo desta ideologia e sua indiscutível vontade imobilizadora. (FREIRE, 1996, pp. 21-22)

Cair na desesperança, no sentimento de impotência é se entregar ao fatalismo, e nele "[...] não é possível juntar forças indispensáveis para o embate recriador do mundo" (FREIRE, 1992, p. 10), além do que esse sentimento de impotência é reflexo da forma como as forças de poder atuam em nossa subjetividade.

De acordo com Santos (2000), o modelo de racionalidade hegemônico, que atua sobre nós e que produz esse sentimento de impotência, é o modelo de racionalidade ocidental também chamado por ele de razão indolente. Esta tem por objetivo contrair o presente e expandir o futuro. A contração do presente é ocasionada por uma peculiar concepção de totalidade, que transforma o presente em um instante fugidio, "entrincheirado" entre o passado e o futuro. Dessa forma, ao contrair o presente, essa razão procura transformar as experiências sociais do mundo como inexistentes, insignificantes, localizadas.

Ao reduzir o presente, a razão indolente produz nas subjetividades o sentimento da não-existência ${ }^{18}$, reforçando a ideia de que nada está acontecendo ou vai acontecer e, por isso, não temos nada a fazer, uma vez que o futuro já está definido. A partir dessa lógica nasce o desânimo, a descrença, a falta de esperança, o pensamento fatalista de fim da história.

Santos afirma que a teoria do fim da história interessa à burguesia, pois o fim da história significaria a repetição infinita do presente.

A verdade é que a repetição do presente é a repetição da fome e da miséria para uma parte cada vez mais importante da população mundial, é a repetição de novos fascismos transnacionais, públicos e privados, que, sob a capa de uma democracia sem condições democráticas, estão a criar um apartheid global; é, finalmente, a repetição do agravamento dos desequilíbrios ecológicos, da destruição maciça da biodiversidade, da degradação de recursos que até agora garantiram a qualidade de vida na Terra. (SANTOS, 1996, p. 16)

Sabemos que a história não chegou ao seu final e que, na verdade, ela não tem fim. Podemos gestar um outro modelo de racionalidade que Santos (2004) chamou de racionalidade cosmopolita. Essa "nova razão" segue uma trajetória inversa à proposta pela razão indolente: ela propõe expandir o presente e contrair o futuro. Pelo procedimento da sociologia das ausências ${ }^{19}$, procuram-se tornar presentes as experiências produzidas como ausentes, ampliando, assim, o presente. E, por meio da sociologia das emergências ${ }^{20}$, procura-se contrair o futuro, tornando-o objeto de cuidado, pois ele passa a ser visto como possibilidades que vão se constituindo no presente.

Uma das tarefas mais necessárias nesse momento é exatamente analisar o mundo com maior acuidade, percebendo "as globalizações", como afirma Boaventura de Sousa Santos: 
A globalização, longe de ser consensual, é... um vasto e intenso campo de conflitos entre grupos sociais, Estados e interesses hegemônicos, por um lado, e grupos sociais, Estados e interesses subalternos, por outro; e mesmo no interior do campo hegemônico há divisões mais ou menos significativas. (SANTOS, 2001, p. 33)

Boaventura de Sousa Santos (2001) detecta dois grandes movimentos de globalização: a "globalização hegemônica", liderada pelas empresas transnacionais, pelos organismos financeiros internacionais e capitalistas dos países centrais, e a "globalização contra-hegemônica", representada pelos movimentos sociais, ONGs progressistas e que vem se articulando nos Fóruns Sociais Mundiais. Esses movimentos ocorrem a partir das três principais contradições vistas por esse autor no período atual: entre o global e o local; entre o Estado-Nação e o não-Estado transnacional; e entre os que veem a globalização neoliberal como inexorável e os que apontam um caminho alternativo de caráter anticapitalista.

\section{Educação popular para reacender a "chama da esperança" na construção de "um outro mundo possível"}

Grandes são os desafios atuais dos movimentos sociais e da Educação popular com seu projeto emancipatório. Trata-se de combater a trivialização do sofrimento humano. Podemos dizer que "[...] o objetivo principal do projeto educativo emancipatório consiste em recuperar a capacidade de espanto e de indignação e orientá-la para a formação de subjetividades inconformistas e rebeldes" (SANTOS, 1996, p. 17). A Educação popular é, assim, um projeto de memória, denúncia e anúncio.

Após a revisita ao contexto sociopolítico vivido no último período e à história da Educação popular no Brasil, podemos reafirmar, a partir de Freire (2000), que essa concepção de Educação e metodologia tem muito a contribuir na resistência das classes populares no jogo de disputas de forças, às vezes invisíveis, que sustenta o capitalismo neoliberal.

O potencial desse projeto político de Educação está presente na forma como, mesmo diante de muitas dificuldades e precariedades, a Educação popular sobreviveu às ações de desmobilização e desmonte dos movimentos populares. Ela não só resistiu e permaneceu atuante, como contribuiu para que educadores e educadoras levassem para as escolas o que aprenderam em sua militância política nos movimentos sociais e sindicais. Os governos democráticos e populares, que foram ganhando espaço na sociedade brasileira a partir dos anos 80, também se apoiaram nas experiências de Educação popular para definição de políticas educacionais.

Um exemplo que podemos citar foi a gestão democrática e popular do PT na cidade de São Paulo. Eleita como prefeita do município, em 1989, Luiza Erundina convidou Paulo Freire para assumir a Secretaria de Educação. Freire, em sua gestão, “[...] comprometeu-se com a construção de uma educação pública popular, tendo como característica principal a Educação como prática da liberdade" (SAUL, 1998, p. 156).

Criou o Movimento de Alfabetização de Jovens e Adultos (Mova) a partir de sua compreensão de educação popular (...). O Mova-SP tornou-se modelo de educação popular e de alfabetização de adultos para muitas 
das secretarias municipais de educação de governos progressistas e outras instituições educativas. (FREIRE, 2005, p. 23)

Sua gestão foi um permanente exercício de diálogo com os educadores e as educadoras, funcionários/as, pais e educandos/as. Experimentou o pensar, o decidir e o fazer com os outros, uma forma de gestão democrática e participativa na Secretaria Municipal de Educação (SME).

Freire buscou desconstruir a idéia de poder centralizado e hierarquizado, descentralizando a administração da SME. Também, através da reinvenção das relações de poder, propôs trabalhos coletivos e envolvimento com toda a comunidade escolar. Todo um trabalho humano se fez necessário para que a "cara" da escola pudesse se transformar. (PEREIRA, 2006, p. 58)

Os princípios de participação popular espalharam-se e passamos a conhecer experiências populares e participativas no campo da saúde, da assistência social, da cultura, bem como na discussão sobre o orçamento dos municípios com gestões democráticas e populares. A partir dessas experiências, diversas são as ações que aconteceram fora e dentro da escola e demonstraram que a Educação popular pode possibilitar a conscientização, a compreensão da realidade, abrindo campos de ação concreta no mundo. Podemos dizer que se apresenta como uma fonte de inspiração ou um fundamento teórico-prático que nos auxilia muito nesse processo de reinventar o mundo.

A conscientização implica, pois, que ultrapassemos a esfera espontânea de apreensão da realidade, para chegarmos a uma esfera crítica, na qual a realidade se dá como objeto cognoscível e o homem assume uma posição epistemológica. (FREIRE, 1980, p. 26)

A Educação popular é um território de denúncias e anúncios de que a história não chegou ao final; por isso é importante ressaltar que:

Nenhuma realidade é porque tem que ser. A realidade pode e deve ser mutável, deve ser transformável. Mas, para justificar os interesses que obstaculizam a mudança, é preciso dizer que "é assim mesmo". O discurso da impossibilidade é, portanto, um discurso ideológico e reacionário. Para confrontar o discurso ideológico da impossibilidade de mudar, tem-se de fazer um discurso também ideológico de que tudo pode mudar. Eu não aceito, eu recuso completamente essa afirmação, profundamente pessimista, de que não é possível mudar. (FREIRE, 2001, p. 169)

Falar em Educação popular, hoje, é falar do conflito que move a humanidade; é falar dos sonhos e ao mesmo tempo dos sofrimentos humanos. É falar de uma perspectiva de Educação cujo ponto de partida é a realidade social, que tem como objetivo reacender "a chama da esperança", a crença de que "um outro mundo é possível", por meio de novas formas de participação social, rumo à construção de uma sociedade mais justa e mais humana.

É por essa experimentação do homem no mundo, e vice-versa, que se adquire conhecimento e se cria o inédito viável, motivo pelo qual a Educação popular, desde seu 
nascimento, não concebe o educando como "recipiente vazio" (FREIRE, 1974), mas como um ser pensante, curioso e criativo.

A Educação popular procura construir uma relação dialógica entre educador e educando. O diálogo é o caminho para o conhecimento, pois, por meio dele, inicia-se a construção de vínculos mais verdadeiros entre as pessoas envolvidas. $\mathrm{O}$ educador busca problematizar a situação em questão, estimulando o educando a observar pontos que não havia percebido, a olhar um mesmo tema por outro ângulo, a comparar situações semelhantes ou divergentes.

Falando da vida, educadores e educandos vão compartilhando narrativas e recuperando a própria memória. A relação entre educador e educando vai se consolidando por meio de trocas mais significativas e verdadeiras, capazes de acordar o potencial criador silenciado dentro dos dois. O educador não é somente um transmissor de conhecimentos, e o educando não é apenas um receptor; o que deve existir entre eles é uma relação de colaboração e troca de saberes, na qual os saberes presentes na comunidade são reconhecidos e validados. Com esse trabalho, as experiências locais de participação popular se fortalecem, e "um outro mundo possível" vai se configurando, na medida em que criamos novos territórios de experimentações capazes de dar sustentação para a construção de um projeto histórico nacional voltado para a criação de uma sociedade justa e igualitária, enfatizando a solidariedade de todos os setores que possam compartilhar e colaborar com esse projeto.

"A partir dessa perspectiva, pode-se dizer que os projetos de Educação popular são os que implicam, ao mesmo tempo, maiores desafios e maiores potencialidades, tanto educacionais como sociais" (WERTHEIM, 1985, p. 60).

Os grupos de Educação popular apresentam-se como um espaço de cultivar a esperança, pois ter esperança implica uma permanente busca impaciente paciente.

Sem um mínimo de esperança, não podemos sequer começar o embate, mas, sem o embate, a esperança, como necessidade ontológica, se desarvora, se "desendereça", e se torna desesperança que, às vezes, se alonga em trágico desespero. Daí a necessidade de uma certa educação da esperança. [...] Enquanto necessidade ontológica, a esperança precisa da prática para tornar-se concretude histórica. É por isso que não há esperança na pura espera, nem tampouco se alcança o que se espera na espera pura, que vira, assim, espera vã. (FREIRE, 1992, p. 11)

"Pensar a questão da Educação popular em uma conjuntura de crise pode também evocar uma imagem de abrir uma janela. É possível que a crise nos leve a abrir janelas que não abriríamos caso não houvesse a crise" (VALLA, 1998, p. 4). Os abalos que a crise provoca na sociedade anunciam que existem possibilidades de reinventarmos o mundo.

No momento em que vivemos tempos de globalização e assistimos à desvalorização das experiências locais e da própria vida, retomar o debate sobre a Educação popular é um potente instrumento de luta contra o desperdício dessas experiências.

Ao investirmos no reconhecimento, na validação e valorização dos saberes presentes nas experiências de Educação popular, estamos percorrendo uma lógica inversa à lógica do mercado. Estamos investindo na potência das experiências locais como campo de produção de "outras globalizações" (SANTOS, 2001), outras formas de trocas, outros modos de existir. Estamos reafirmando que a história não chegou ao final e que

[...] o futuro não é, por exemplo, a pura repetição de um presente de insatisfações. O futuro é algo que vai 'se dando', significa que o futuro 
existe na medida em que eu ou nós mudamos o presente. E é mudando o presente que a gente fabrica o futuro; por isso, então a história é possibilidade e não determinação. (FREIRE, 1995, p. 90)

Reafirmamos que a Educação popular é um laboratório de experimentação, busca desvendar e reinventar o mundo. Possibilita encontros humanos mais verdadeiros e significativos, estimula a produção de conhecimentos que nos ajudam a construir uma vida melhor.

Quando o conhecimento é produzido com base na emancipação humana, ele nos ajuda a romper com a lógica do mercado capitalista que nos apresenta o consumo como a solução para nossos problemas e a satisfação de nossos desejos. Na Educação popular podemos criar outras formas de troca. Enfim, podemos colocar "a vida a serviço da vida" (Thiago de Mello). Colocar "a vida a serviço da vida" não é fazer discursos, mas se lançar no movimento de reinvenção do mundo em busca de uma sociedade mais justa e mais humana.

\section{Referências Bibliográficas}

ALENCAR, F. "Associações de moradores e a construção da democracia”. Revista Tempo e Presença. São Paulo: Cedi, n. 225, novembro de 1987.

ANPEd. XXI Reunião Anual: GT6. Caxambu/MG, 1998.

BARRETO, J.C. Educação na visão de Paulo Freire. São Paulo: Vereda/Centro de Estudos em Educação, 1986.

BEISIEGEL, C. de R. Política e Educação Popular: a teoria e a prática de Paulo Freire no Brasil. São Paulo: Ática, 1989.

BRANDÃO, C.R. História do menino que lia o mundo. 3. ed. Veranópolis/RS: Iterra Instituto de Capacitação e Pesquisa da Reforma Agrária, 2001.

CALDART, R.S. \& KOLLING, E.J. Paulo Freire: um educador do povo. Veranópolis/RS: MST, 2001.

DAGNINO, E. (org.) Sociedade civil e espaços públicos no Brasil. Rio de Janeiro: Paz e Terra, 2002.

DOWBOR, L. "Prefácio". In: FREIRE, P. À sombra desta mangueira. São Paulo: Olho d'Água, 1995.

DREIFUSS, R.A. 1964: a conquista do Estado. Petrópolis/RJ: Vozes, 1981.

FÁVERO, O. (org.) Cultura popular: memória dos anos 60. Rio de Janeiro: Edições Graal, 1983.

FREIRE, A.M. de A. (org.) Pedagogia dos sonhos possíveis. São Paulo: Unesp, 2001.

"Utopia peregrina". Revista Memória da Pedagogia: Paulo Freire: a utopia

do saber. n. 4. São Paulo: Segmento-Dueto, 2005. pp. 16-29.

FREIRE, P. Uma educação para a liberdade. Porto/Portugal: Textos Marginais, 1974.

Conscientização: teoria e prática da libertação. São Paulo: Moraes, 1980.

Educação como prática de liberdade. 13. ed. São Paulo: Paz e Terra,

1982a.

Extensão ou comunicação? Tradução de Rosisca Darcy de Oliveira. Rio de Janeiro: Paz e Terra, 1982b.

Educação e mudança. 6. ed. São Paulo: Paz e Terra, 1983.

Pedagogia do oprimido. 17. ed. Rio de Janeiro: Paz e Terra, 1987.

Pedagogia da esperança: um reencontro com a pedagogia do oprimido.

3. ed. São Paulo: Paz e Terra, 1992. 
Pedagogia da autonomia: saberes necessários à prática educativa. 10. ed. Rio de Janeiro: Paz e Terra, 1996.

Política e Educação. 4. ed. São Paulo: Cortez, 2000.

GENTILI, P. et al. Globalização excludente: desigualdade, exclusão e democracia na nova ordem mundial. 3. ed. Petrópolis/RJ: Vozes; Buenos Aires: Clacso, 2000.

GUISO, A. "Entre revisões e reinvenções". In: SILVA, L.H. da \& AZEVEDO, J.C. de (orgs.) Petrópolis/RJ: Vozes, 1995.

MEB. Relatório trienal - 1990 a 1992. Brasília: MEB, 1993.

NÓVOA, A. (orgs.) Paulo Freire: política e pedagogia. Porto/Portugal: Ed. Porto, 1998. pp. 151-166.

PAIVA, V. (org.) Perspectivas e dilemas da Educação popular. Rio de Janeiro: Edições Graal, 1984.

1987.

Educação popular e Educação de adultos. São Paulo: Edições Loyola,

PEREIRA, D. de F.F. Revisitar Paulo Freire: uma possibilidade de reencantar a Educação. 2006. Tese. Doutorado em Educação pela Faculdade de Educação da Unicamp, Campinas, 2006.

PEREIRA, E.T. Formar à esquerda: processo de educação política no PT e na CUT, um estudo sobre a Fundação Nativo da Natividade. São Paulo: Terras do Sonhar; Pulsar, 2006.

Educação política: uma experiência com o orçamento participativo. Campinas/SP: Alínea, 2008.

SANTOS, B.S. "Por uma Pedagogia do conflito". In: SILVA, L.H. da. Novos mapas culturais, novas perspectivas educacionais. Porto Alegre:Sulina, 1996.

A crítica da razão indolente: contra o desperdício da experiência. 2. ed. São Paulo: Cortez, 2000.

. "Os processos da globalização". In: Globalização: fatalidade ou utopia? Porto/Portugal: Afrontamento, 2001. pp. 31-106.

(org.) "Para uma sociologia das ausências e uma sociologia das emergências". In: Conhecimento prudente para uma vida decente: 'Um discurso sobre as Ciências' revisitado. São Paulo: Cortez, 2004. pp. 777-821.

SAUL, A.M. "A construção do currículo na teoria e prática de Paulo Freire". In: APPLE, M. \&

SAVIANI, D. "Os ganhos da década perdida". Revista Presença Pedagógica. Editora Dimensão, v. 1, n. 9, nov./dez. de 1995.

SILVA, F. de A. História do Brasil: Colônia, Império e República. São Paulo: Moderna, 1992.

STIGLITZ, J.E. Globalização: a grande desilusão. Lisboa/Portugal: Terramar, 2002.

STRECK, D.R. Pedagogia no encontro de tempos: ensaios inspirados em Paulo Freire. Petrópolis/RJ: Vozes, 2001.

VALE, A.M. do. Educação popular na Escola Pública. São Paulo: Cortez, 1992.

VALLA, V.V. A revalorização da Educação popular numa conjuntura de crise.

WERTHEIN, J. (org.) Educação de Adultos na América Latina. Campinas/SP: Papirus, 1985.

\section{Notas}

\footnotetext{
${ }^{1}$ Doutora em Educação pela Unicamp e professora adjunta da UFSCar/Campus Sorocaba/SP.

${ }^{2}$ Doutor em Educação pela Unicamp e professor da UniAnchieta/Jundiaí/SP.
} 
${ }^{3}$ O neoliberalismo expressa uma saída política, econômica, jurídica e cultural específica para a crise hegemônica que a economia do mundo capitalista começa a atravessar, como produto do esgotamento do regime de acumulação fordista iniciado a partir do fim dos anos 60 e começo dos 70. O(s) neoliberalismo(s) expressa(m) a necessidade de restabelecer a hegemonia burguesa no quadro dessa nova configuração do capitalismo em um sentido global (GENTILI, 2000, p. 230).

${ }^{4}$ Quando se fala em homem-pessoa e homem-coisa, é preciso se lembrar do que Freire nos diz, pois ele "[...] reconhece o homem como um ser histórico, que desmistifica a realidade, razão porque não teme a sua desocultação. Em lugar do homem-coisa adaptável, luta pelo homem-pessoa, transformador do mundo". (FREIRE, 1974, p. 17).

5 Educação bancária: "faz do processo educativo um acto permanente de depositar conteúdos. Acto no qual o depositante é o 'educador' e o depositário é o 'educando'. A concepção bancária, ao não superar a contradição educador-educando, mas, pelo contrário, ao enfatizá-la, não pode servir senão à 'domesticação' do homem". (FREIRE, 1974, p. 14).

${ }^{6}$ Conforme Dreifuss (1981), o populismo constituía-se em uma forma de dominação em que políticos profissionais estabeleciam um mecanismo de aparente mobilização popular, contida e controlada, com uma prática de colaboração de classes e uma estrutura de apaziguamento dos conflitos.

7 “Os diversos relatos disponíveis sobre a criação do Movimento de Cultura Popular (MCP) coincidem em afirmar que ele foi instituído sob a inspiração e o patrocínio direto da Prefeitura de Recife. Em maio de 1960, o então prefeito Miguel Arraes promoveu, apoiado em setores progressistas da intelectualidade e nos estudantes, a fundação do Movimento de Cultura Popular. Juridicamente, nascia o MCP como uma sociedade civil autônoma. Suas atividades iniciais se orientaram, fundamentalmente, no sentido de conscientizar as massas através da alfabetização e educação de base. A realidade de um Estado com enorme índice de analfabetismo exigia esforços urgentes a fim de incorporar à sociedade os milhares de proletários e marginais de Recife, dotando-os de uma nova consciência. Com o tempo, o MCP foi diversificando seu campo de ação, e novos tipos de contato com a massa se foram forjando: teatro, núcleos de cultura popular, meios informais de educação, canto, música e dança popular, artes plásticas e artesanato" (BEISIEGEL, 1989, p. 119).

8 "Não era só levar para a gente dos bairros pobres aquilo que se podia assistir no dos ricos. O pessoal do MCP sabia que todas as pessoas, todas as famílias, todas as comunidades e todo mundo tinham a sua própria cultura. Você vai em um 'fundo do mundo', vai lá em um "oco do sertão" e lá vive uma gente. E vive como gente, as pessoas falam umas com as outras e se entendem. Elas criam famílias. Elas plantam na terra e colhem. Fazem a comida e sabem orações que se rezam antes de comer. Pintam potes de barro, criam canções bonitas e fazem lindas colchas de fiandeira. As pessoas "de lá" têm seus conhecimentos sobre as plantas e os bichos e sabem tratar muitas doenças. Elas têm os seus muitos cantos e as suas alegres danças. Elas criam e possuem as suas crenças e os seus saberes. Isso mesmo. Povo nenhum, dos índios da Amazônia a São Paulo ou Rio de Janeiro, vive sem conviver com tudo isso. E é assim que se fala que cada gente, cada povo do Brasil e do Mundo possui uma CULTURA própria” (BRANDÃO, 2001, p. 37).

9 “Toda invasão sugere, obviamente, um sujeito que invade. Seu espaço histórico-cultural, que lhe dá visão de mundo, é o espaço de onde ele parte para penetrar em outro espaço histórico-cultural, superpondo aos outros indivíduos seu sistema de valores. $\mathrm{O}$ invasor reduz os homens do espaço invadido a meros objetivos de sua ação. As relações entre invasor e invadidos, que são relações autoritárias, situam seus pólos em relações antagônicas. O primeiro atua, os segundos têm a ilusão de que atuam na atuação do primeiro; este diz a palavra; os segundos, proibidos de dizer a sua, escutam a palavra do primeiro. $\mathrm{O}$ invasor pensa, na melhor das hipóteses sobre os segundos, jamais com eles; estes são pensados por aqueles. O invasor prescreve e os invadidos são pacientes da prescrição" (FREIRE, 1982b, pp. 41-42).

10 "Em lugar de professor, com tradições fortemente 'doadoras', o Coordenador de Debates. Em lugar de aulas discursivas, o diálogo. Em lugar de aluno, com tradições passivas, o participante de grupo. Em lugar dos 'pontos' e de programas alienados, programação compacta, 'reduzida' e 'codificada' em unidades de aprendizado" (FREIRE, 1980, p. 103).

11 “A conscientização é um compromisso histórico. É também consciência histórica: é inserção crítica na história, implica que os homens assumam o papel de sujeitos que fazem e refazem o mundo. [...] A conscientização, como atitude crítica dos homens na história, não terminará jamais. [...] A conscientização nos convida a assumir uma posição utópica frente ao mundo, posição esta que converte o conscientizado em "fator utópico"” (FREIRE, 1980, p. 27).

12 "O percurso político intelectual de Freire ilustra, de maneira exemplar, o que ocorreu com boa parte da intelectualidade católica brasileira. Preocupado desde os anos 50 com o tema do desenvolvimento, com a busca de estratégia para 'vencer o atraso', sendo capaz - embora católico - de aceitar o mundo moderno, a civilização industrial, Freire aderiu ao nacionalismo desenvolvimentista. Os temores manifestados no pensamento católico com a massificação provocada pela sociedade industrial, com o desenraizamento 
resultante da migração rural-urbana, com a manipulação política das massas urbanas, aparecem em seu trabalho como denúncia do risco do desenvolvimento: a educação das massas como seu antídoto. Na obra de Freire, a aceitação do desenvolvimento capitalista nacional foi se convertendo em rejeição ao capitalismo e em opção pelo socialismo, em nome - tal como ocorreu com os jovens católicos - não apenas dos custos sociais do capitalismo, mas também dos seus malefícios no que diz respeito à formação de pessoas autônomas e solidárias. O capitalismo deveria ser combatido porque a estrutura socioeconômica a ele correspondente implicava o individualismo, o consumismo, a alienação, a perda das formas de solidariedade vicinal, a destruição de valores cristãos e da religiosidade do povo, a sua manipulação política e, finalmente, a sua massificação - a incapacidade de cada pessoa decidir por si mesma de maneira autônoma a respeito de sua vida e de sua presença na sociedade. A rejeição ao capitalismo passou entre as forças católicas que evoluíram para uma posição de esquerda" (PAIVA, 1984, p. 245).

13 “A renovação católica a partir do Concílio Vaticano II abriu caminho para um tipo de participação de leigos e religiosos na Igreja que permitia levantar objeções ao autoritarismo tradicionalmente reinante na instituição; o movimento de renovação patrística, a proposta de retorno à Igreja primitiva, era reforçado pela aceitação do Vaticano II da idéia de que a Igreja não é a Hierarquia, mas o povo de Deus, gerando um clima propício à contestação do autoritarismo no interior da Igreja" (PAIVA, 1984).

${ }^{14}$ Confira, por exemplo, o interessante trabalho desempenhado nesse momento no Brasil pela "Teologia da Libertação" e seu principal instrumento de ação social e de evangelização, as Comunidades Eclesiais de Base (CEBs). É historicamente inequívoca a afirmação de que as CEBs colaboram de maneira muito significativa no processo de luta para que no Brasil se retomasse o processo de reconstrução democrática.

${ }^{15}$ Trecho da música $O$ bêbado e a equilibrista de João Bosco e Aldir Blanc.

${ }^{16} \mathrm{O}$ conceito de exclusão é relativamente recente na linguagem das ciências humanas e sociais, embora por trás dele se esconda uma realidade nada nova. São por demais conhecidos os fatos da fome, da convivência com a injustiça, do não-acesso aos meios de saúde e educação, da discriminação de raça e gênero, enfim, tudo aquilo que faz com que alguém seja "menos gente". A linguagem nova é sinal de que essa mesma realidade se apresenta com cara diferente e, portanto, como um novo desafio prático e epistemológico. (STRECK, 2001, p. 51)

${ }^{17}$ Quando falamos em "um outro mundo possível", inspiramo-nos nos Fóruns Sociais Mundiais que vêm procurando discutir e apontar alternativas possíveis para o contexto em que estamos vivendo.

18 "Não há uma maneira única de não existir, porque são várias as lógicas e os processos por meio dos quais a razão metonímica produz a não-existência do que não cabe na sua totalidade e no seu tempo linear. Há produção de não-existência sempre que uma dada entidade é desqualificada e tornada invisível, ininteligível, ou descartável de modo irreversível" (SANTOS, 2004, p. 787).

Santos (ibidem) distingue cinco lógicas ou modos de produção da não-existência:

1- Monocultura do saber e do rigor do saber;

2- Monocultura do tempo linear;

3- Lógica da classificação social;

4- Lógica da escala dominante;

5- Lógica produtivista.

A partir dessas lógicas, são cinco as formas sociais de não-existência produzidas ou legitimadas pela razão metonímica:

1- O ignorante;

2- $\mathrm{O}$ residual;

3- O inferior;

4- O local;

5- O improdutivo.

19 "A sociologia das ausências trata-se de uma investigação que visa demonstrar que o que não existe é, na verdade, activamente produzido como não existente, isto é, como uma alternativa não credível ao que existe [...] o objetivo da sociologia das ausências é transformar objetos impossíveis em possíveis e com base neles transformar as ausências em presenças" (ibidem, p. 786).

20 "A sociologia das emergências consiste em substituir o vazio do futuro, segundo o tempo linear (um vazio que tanto é tudo quanto é nada), por um futuro de possibilidades plurais e concretas, simultaneamente utópicas e realistas, que se vão construindo no presente através da actividade do cuidado" (ibidem, p. 794).

Artigo recebido em: $\quad 22 / 11 / 2010$

Aprovado em: $\quad 10 / 12 / 2010$ 